\title{
The EU Export Controls Regime: Dual-Use Goods and Technologies in the European Legal Framework
}

\author{
By Hamed Alavi* and Tatsiana KhamichonaK**
}

\begin{abstract}
Dual-use items, including software and technology, can be used for both civil and military purposes. Export control of such items is an important constituent part of security policies of exporter states. These measures are aimed at avoiding proliferation of weapons of mass destruction. ${ }^{1}$ The nature of dual-use goods intrigues imposition of control over exporting them to unfriendly countries or those 'sensitive' in terms of their ambiguous considerations of foreign policies. ${ }^{2}$ Some category of goods may be banned for export, whilst others are legitimate products that further technological development and strengthen international economic ties. The aim of the exporter states is to seek balance between safeguarding security objectives whilst not undermining competitiveness of local businesses. The paper explores the EU framework for regulating exports of dual-use goods as well as the EU participation in the international export controls regimes.
\end{abstract}

Keywords: dual-use items, security policy, weapons of mass destruction, export control

\section{INTRODUCTION}

The EU export controls regime has experienced development of competences over the years since the first Council Regulation ${ }^{3}$ of 1994, when the initial step was made towards a Community regime for the control of exports of dual-use goods. ${ }^{4}$ The Lisbon Treaty allocated dual-use goods and technologies under the EU's control of exports of dual-use goods and technologies under the EU's trade policy instead of the preceding common market and competition rules, resulted in Member States gradually surrendering exclusive control of dual-use goods' exports authorization procedures to the European Commission. Today an authorization is required in the form of a license for all non-EU transfers of indicated items, whereas intra-EU circulation is harmonized and simplified to a certain extent. This regime is not without pitfalls, as the Commission is only exercising partial control over the respective Member States' decisions. Another weak link is the lowest common denominator harmonization of respective rules Member States apply to regulate export controls.

The paper gives an outline of the existing export controls regime in the EU as shaped by the relatively short history of relevant Union legislation. An overview is given of the provisions of Council Regulation 428/2009 and of the role of the major export controls groups, i.e. the Wassenaar Agreement, the Missile Technology Control Regime (MTCR), the Australia Group (AG) and the Nuclear Suppliers Group (NSG). The pitfalls of the EU export controls regime are also assessed, weighted and the currently negotiated amendments to the regime are addressed.

\footnotetext{
* Lecturer, Tallin Law School, Tallin University of Technology. E-mail: hamed.alavi@ttu.ee

** LLM Candidate, Vrije Iniversiteit, Amsterdam. E-mail: tatsiana.khamichonak@hotmail.com

1 Micara (2012) 578-593.

2 Micara (2012) 578.

3 Council Regulation 3381/94 (1994).

${ }^{4}$ Fiott (2013).
} 


\section{THE FRAMEWORK OF THE EU INTERNATIONAL COMMITMENTS IN THE AREA OF EXPORT CONTROLS}

Export Controls is a trade instrument, specifically designated to uphold international security objectives in the framework of non-proliferation of weapons of mass destruction (WMD). The threats to security and safety are high due to the emergence of various forms of terrorism and the efforts of state- and non-state actors to acquire WMD and complementary technologies. It is estimated that up to $10 \%$ of exports from the EU is allocated to dual-use goods and technologies with over 5000 companies engaged in the export of controlled dual-use items. ${ }^{5}$ Annex I to the Regulation No 428/2009 illustrates, that dual-use goods are extremely broadly interpreted covering such industries, including inter alia, nuclear, biological, chemical as well as computers, telecommunications, encryption, navigation and avionics. Due to their nature, dual-use goods are state-of-the-art advanced items that can only be acquired globally from a very limited number of states-exporters. Many of the states-exporters belong to all or some of the four international export controls regimes: the Australia Group, the Missile Technology Control Regime, the Nuclear Suppliers Group and the Wassenaar Arrangement. They all operate with the mandate of preventing dual-use items being used for military purposes or the production of WMD. ${ }^{6}$ However, not all of exporting states are committed to controlling exports of dual-use items or establishing efficient export-control regimes. The inefficient or inexistent control makes a number of sensitive items available on the market. Foreign availability of dual-use goods is one of the major considerations, that affects the decision of whether to exercise control due to the need of balancing security concerns with economic development and competitiveness of EU exporters on the global market.

The UN Security Council has consistently affirmed that the proliferation of nuclear, chemical and biological weapons constitutes a threat to international peace and security. ${ }^{7}$ The existing WMD non-proliferation national and international measures and the systems of implementation raise doubts about their effectiveness when considering the nuclear potential of India, Israel and Pakistan or North Korea to international peace and security. ${ }^{8}$ These worries brought global WMD non-proliferation efforts to the forefront of security concerns. An important constituent part of WMD non-proliferation is a strong system of export controls of dual-use goods and technologies. The 1980s transfers of sensitive items by individuals and companies from within the EU indicate the need for effective export control provisions, as well as mechanisms of their monitoring and implementation. ${ }^{9}$ In Resolution 1540, the Security Council called upon the UN Member States to refrain from providing any support to non-state actors, who attempt to acquire WMD, and effective domestic non-proliferation controls where established in conjunction with a strengthening of their international commitments to facilitate this policy. ${ }^{10}$

5 European Commission Green Paper tutee for European Studies, VUB, Belgium. Civil and military purposes. Export control of such oneness in a changing world Paper tutee for Europe.

${ }^{6}$ European Commission Green Paper (2011) 4.

7 UNSC Resolution 687 (1991).

8 Wetter (2009).

9 The Abdul Qadeer Khan network of private actors sold sensitive products and technology while exploiting the Dutch market. In 1990s German companies selling sensitive items to Iraq were exposed. See Wetter (2009) 2.

10 UNSC Resolution 1540 (2004). 
The European Council adopted the European Security Strategy (ESS) ${ }^{11}$ in 2003, which identifies proliferation of WMD as the greatest threat to security, outweighing terrorism, organized crime, regional conflicts and state failure. The Council, with the ESS, adopted the WMD Strategy and its Plan of Action. ${ }^{12}$ The measures in Chapter III of the Strategy, referred as the 'living action plan', focus on the implementation and strengthening of the EU WMD non-proliferation strategy throughout all available instruments. The instruments including, nationally- and internationally-coordinated export controls, multilateral treaties, verification mechanisms and threat reduction programs. ${ }^{13}$ The Strategy refers to export controls particularly the strengthening export control strategies and practices in cooperation with partners; reinforcing efficiency of export controls in the enlarged Europe; providing assistance with technical knowledge in the area of export controls; reinforcing export controls with regard to intangible transfers of dual-use technology and facilitating information exchange between Member States. ${ }^{14}$

The EU has grown from 15 to 28 Member States since the adoption of the WMD Strategy in 2003. The enlargements have changed the inner dynamics of the EU and the effectiveness of the system of export controls in the larger Europe has come into question. ${ }^{15}$ The WMD Strategy prioritize the enhancement of EU export control policies but, many newly incorporated states did not have effective export controls and were not members of the four export control regimes. ${ }^{16}$ The implications were that their accession would provide access to the EU common market, where the free movement of dual-use goods was established, and would create a proliferation threat. The resolution of this issue was a high priority in 2005-2006, when the peer review of export controls in current and acceding countries, provided for in the WMD Strategy, was completed. ${ }^{17}$ In 2008, the Council adopted the accession would provide access to the EU common market, where the free movement of dual-use goods was established, and would their delivery systems which reflects on the efforts and outcomes of the implementation of the WMD Strategy and sought further strengthening it. ${ }^{18}$ The report reaffirmed that WMD misappropriated by terrorists or non-state actors constitute re the free moeatest security challenges which Europeans may have ever faced.' ${ }^{19}$ Therefore, the relevancy of the WMD Strategy of 2003 shall not be underestimated and should be considered, with importance even more so that it realises the UNSC Regulation 1540 guidelines, which are the cornerstone of international nonproliferation strategies. ${ }^{20}$

11 UNSC Resolution 1540 Better World', European Security Strategy, Brussels, 12 December 2003.

12 EU strategy against proliferation of Weapons of Mass Destruction, 15708/03, Brussels, 10 December 2003.

13 EU strategy against proliferation of Weapons of Mass Destruction (2003), 0329.

14 EU strategy against proliferation of Weapons of Mass Destruction (2003).

15 Anthony (2013).

16 Anthony (2013) 17.

17 Anthony (2013) 18.

18 Council Conclusions 17172/08, Brussels, 17 December 2008.

19 Council Conclusions 17172/08, 3.

20 Council Conclusions 17172/08, 4. 


\subsection{EU participation in international export controls groups}

The EU and Member States participate in the Australia Group, the Wassenaar Arrangement, the Missile Technology Control Regime and the Nuclear Suppliers Group, in different capacities.

The Australia Group (AG) is an informal commitment, through which countries undertake to ensure that exports do not contribute to the development of chemical and biological weapons, This is realized by harmonizing national export control measures in pursuit of the fulfilment of their obligations under the Chemical Weapons and Bio- and Toxic Weapons Conventions. All the AG participants are State Parties to both Conventions and the 1925 Geneva Protocol. The first meeting of the then 15 participants and the European Commission took place in 1985 in Brussels as a response to the 1984 UN discoveries of Iraq's use of chemical weapons (nerve agents and sulphur mustard) in violation of the 1925 Geneva Protocol. With the evolution of threats and the variety of the dual-use materials that can be used in the production of chemical and biological weapons, specific biological agents were included in the scope of AG cooperation in the early 1990s. The harmonization of exports among the AG members is achieved through licensing exports of certain chemicals, bio-agents and dual-use chemical and bio-manufacturing facilities. The number of AG members has grown from 15 in 1985 to 41 and includes the EU as a member of its own right. ${ }^{21}$

The Wassenaar Arrangement (WA) on Export Controls for Conventional Arms and Dual-use Goods and Technologies is an intergovernmental arrangement established in July 1996 by 33 states including the U.S., Great Britain, Russia, France, Canada and Japan. ${ }^{22}$ The WA replaced CoCom, which was no longer considered to be an appropriate basis for export controls, but unlike CoCom, WA is open to all countries on a non-discriminatory basis, and is not directed against any state or group of states, and many of former Warsaw Pact countries are now members of WA. The WA members undertake to ensure that transfers of conventional arms and dual-use items do not contribute to the development of military capabilities and do not undermine international and regional peace and security. ${ }^{23}$ The WA particularly seeks to complement and reinforce the existing control regimes for WMD and their delivery systems; enhances cooperation to prevent the acquisition of arms and dualuse items by terrorist groups and organizations as well as by states and other end-users, if the situation in the region becomes a cause of serious concern. ${ }^{24}$ As of 2012, the number of WA participants increased to 41 states with the European Commission participating within the delegations of EU presidencies.

The Missile Technology Control Regime (MTCR) is an informal association of states established by Canada, France, Germany, Italy, Japan, the UK and the U.S. in 1987. The association'stablished by Canada, France, Germany, Italy, Japan, the UK and the U.S. inable of WMD delivery and to coordinate the participating states' national licensing efforts. After the events of $9 / 11$, the focus has also been directed to the prevention of WMD proliferation by terrorist groups and individuals, by monitoring the transfers of missile equipment, material and related technologies capable of delivering WMD. The MTCR has

21 See at $<$ http://www.australiagroup.net/en/index.html> accessed 13 December 2015.

22 August (2013).

23 August (2013) 396.

${ }^{24}$ Wassenaar Arrangement Guidelines \& Procedures, including the Initial Elements, 1996 with amendments. 
no permanent organization. Its activities are based on the MTCR Guidelines and the Equipment, Software and Technology Annex, which lay down rules of participation and export control guidelines for the Annex items. ${ }^{25}$ Currently, there are 34 members with the European Commission participating within the delegations of EU presidencies.

The Nuclear Suppliers Group (NSG) is a group of nuclear supplier countries that aims at non-proliferation of nuclear weapons. NSG operates by the Non-Proliferation Principle through the implementation of two sets of Guidelines for nuclear and nuclear-related exports, which implement various binding international instruments in the field of nuclear non-proliferation: the Treaty on the Non-Proliferation of Nuclear Weapons (NPT), as well as a number of regional agreements. The NSG was created in 1974 following the Indian nuclear explosion, which showed that nuclear technology transferred for peaceful purposes can be misused. In 2013, there were 46 members with the European Commission and the Chair of the Zangger Committee ${ }^{26}$ participating as observers. ${ }^{27}$

\section{THE FORMATION OF EU EXPORT CONTROLS REGIME}

The EU export controls regime is governed by Regulation (EC) No 428/2009, which establishes common control rules and a list of controlled items. While the regulation is binding and directly applicable throughout the EU, it is up to the Member States to adopt policies to implement the Regulation'olicies to implement the Regulationerned by Regulation (EC) No 428/2009, which establishes common control rules and a list of controlled items. While the regulation is bindihat when the Union has exclusive competence in a specific area, the Member States are precluded from legislating in that area unless specifically authorized by the EU. This, however, was not always the case and the history of the Regulation's adoption shows a significant shift of competences from the Member States to the EU.

\subsection{Developments preceding the adoption of Regulation No. 428/2009}

Historically, most of the EU Member States have established national export regimes and participated in international agreements in order to harmonize their export controls systems and ensure WMD non-proliferation. During the Cold War the western countries'their export controls systems and ensure WMD non-proli ${ }^{28}$ countries and overseen by the Coordinating Committee for Multilateral Strategic Export Controls (CoCom). ${ }^{29}$ It was created in 1949 at the initiative of the U.S. between the U.S., Japan and the NATO states except Iceland.

25 See at $<$ http://www.mtcr.info/english/index.html > accessed 13 December 2015.

26 Zangger Committee, a.k.a. Non-Proliferation Treaty Exporters' Committee, was established in 1971, one year after the NPT came into force. The Committee coordinated the member states' interpretations of the NPT's export control provision, which requires exporters to seek International Atomic Energy Agency's (IAEA) safeguards in order to supply nuclear items that are capable of 'processing, use, or production of special fissionable material'. Zangger Committee is less active now with the creation of the NSG. August, Mayer, Bixby (2013) 397.

27 See at $<$ http://www.nuclearsuppliersgroup.org/en/> accessed 13 December 2015

28 The Warsaw Treaty Organization, a.k.a. the Warsaw Pact, was a political and military alliance between the USSR, Albania, Poland, Czechoslovakia, Hungary, Bulgaria, Romania, and the German Democratic Republic, established in 1955 to counterbalance the NATO. The Pact was terminated in July 1991 with the collapse of the Soviet Union.

29 Micara (2012) 578-593. 
The CoCom With its headquarters in Paris was designed to prevent the Eastern bloc from acquiring crucial Western technology and operated three lists of items that should not be exported to the Soviet Union and its allies. ${ }^{30}$

The established systems of export controls by the individual CoCom participating countries with the exclusion of the European institutions negatively impacted the intracommunity and external trade. ${ }^{31}$ The absence of a harmonized Community regime of export controls, and the discrepancies in national systems constituted obstacles to internal trade impaired the free movement of goods within the internal market. This was illustrated by the case Aime Richardt and Les accessoires scientifiques $\mathrm{SNC}^{32}$, which dealt with the unlawful transit of certain goods without a license through the Grand Duchy of Luxembourg. Mr. Richardt, the director of Les Accessoires Scientifiques, prepared to deliver a ten-inch Veeco Microetch (used in the production of bubble memory circuits) to Technopromimport, established in Moscow. After the necessary formalities were completed in France, the direct flight Paris-Moscow was cancelled and the item was transported by lorry to the Luxembourg airport, where it was seized. The seizure occurred because the item was claimed to be accompanied by 'inaccurate declarations in order to conceal its strategic nature and to permit its transit to the USSR' contrary to Luxembourg laws that required a special transit license. ${ }^{33}$ In its ruling, the Court of Justice of the European Union (CJEU) referred to Article 36 of the EEC Treaty, whose purpose is to allow Member States to derogate from the principle of free movement of goods to secure the interests that Article 36 protects. ${ }^{34}$ It provides that the measures that a Member State may employ the justified objective and should not restrict the intra-Community trade more than absolutely necessary. ${ }^{35}$ The security objective invoked to justify the authorization requirement concerns, for the purposes of Article 36 EEC Treaty, was both state's external and internal security. This in conjunction with the transit and export of dual-use goods may affect a state's public security, led the Court to decide that Luxembourg had the right to require a special authorization for the transit of the item in question and its subsequent confiscation. ${ }^{36}$ The judgment illustrated that the internal market lacked effective integration with regard to dual-use goods and technology, and a harmonized system of export controls was required.

In order to bring dual-use goods and technology into the common market by eliminating border controls between Member States, and to coordinate and strengthen control over exports to third countries, the Commission submitted a proposal in 1992 for a Regulation on the control of exports of certain dual-use as well as nuclear goods and technologies. ${ }^{37}$ Five criteria have been indicated in order for border controls to be eliminated: the common list of dual-use goods subject to control; the common list of destination countries; common criteria for issuing export licenses for third-country exports; a mechanism for coordination and enforcement of licenses and, procedures for administrative cooperation between the licensing authorities and customs offices. ${ }^{38}$

30 Gregory (1987) 863-882.

31 Micara (2012) 581.

32 Richardt and 'Les accessoires scientifiques' [1991] ECR C-367/89

33 Richardt and 'Les accessoires scientifiques' (1991), §§ 3-5.

34 Richardt and 'Les accessoires scientifiques'(1991), §§ 19-20.

35 Richardt and 'Les accessoires scientifiques'(1991), § 20.

36 Richardt and 'Les accessoires scientifiques' (1991), §§ 22-23.

$37 \operatorname{COM}(92) 317$.

${ }^{38}$ Leslie (1994) 193-211. 
The Council adopted Regulation No. 3381/94 following the Commission proposal. The Regulation was adopted based on Article 113 of the EC Treaty and became part of the EU Common Commercial Policy (CCP). The Council adopted Decision 94/942/CFSP on the Joint Action at the same time. The Joint Action was adopted within the framework of the EU Common Foreign and Security Policy. The Regulation provided for a system of licenses applicable to dual-use items, whereas the Joint Action prescribed a list of items to be controlled in conformity with the international export control regimes, which Member States should take into account when granting licensing. The two instruments regulated identical issues but coexisted in parallel because of their different legal basis and the separation of power. The new export control system affected did away with the concerns identified in the Richardt case through the mutual recognition of licenses between Member States. ${ }^{39}$ The two instruments experienced a conflict of interest particularly in the area of decision-making despite being designed as an 'integrated system'40. Thus, under Article 113, decisions about certain sensitive issues are to be resolved under Qualified Majority Voting (QMV), which Member States were reluctant to rely on. ${ }^{41}$ Whereas the Commission favored a single European strategy in the area of export controls of dual-use goods, the Member States did not wish to sacrifice their competence in deciding on the controlled goods and export guidelines.

Two hallmark CJEU judgments were the trigger to remove with the two-tier export controls approach. In the Leifer and Werner cases, the Court ruled that exports of dual-use goods must fall exclusively under the CCP. The Court broadly interpreted the CCP, to emphasize that exports of dual-use goods should be treated as trade measures because of their nature, instead of measures having security and foreign policy objectives. ${ }^{42} \mathrm{CCP}$ is an exclusive competence of the EU, and thus the Member States are effectively precluded from acting in this area except with a special authorization. ${ }^{43}$ In line with the judgments, the Commission argued that an EU-wide export control regime is necessary, as it will further the completion of the common market; form strong boundaries on its frontiers and a common export control system will provide greater legal certainty, reducing the burden on exporters as well as establishing a level playing field. ${ }^{44}$

In 2000, the Council Decision on Joint Action was repealed and Regulation 1334/2000 was adopted exclusively under Article 113 EC Treaty, which unified the former two-tier system of rules in one instrument. A common EU export controls regime was established but, some important limitations remained. For example, lists of controlled items are included into the Regulation's text, they are implemented uniformly by the Member States and can be amended in the framework of Commission proposals. However, the proposed amendments to the controlled goods are performed on the basis of the respective agreements of the Member States within the international export control regimes. This limits the Commission's powers as it only participates in the Australia Group in its own right. Along the same line of reasoning, with the EU enlargements in 2004 and 2007, the unequal membership of acceding states in international regimes posed further proliferation concerns

\footnotetext{
39 Micara (2012) 582.

40 Micara (2012) 582.

41 Suzuki (2007).

42 Micara (2012) 583.

43 Craig (2011).

44 Suzuki (2007) 4.
} 
with regard to export controls and the free circulation of controlled items within the internal market. ${ }^{45}$

On 18 December 2006, the Commission submitted a proposal for the amendment and recast of Regulation 1334/2000. ${ }^{46}$ The proposal followed the 2004 peer review of the Regulation's implementation by the Member States, conducted in conformity with the Thessaloniki WMD Strategy and Action Plan in order to meet the standards of the UNSC Resolution 1540. The proposal meant to strengthen the EU dual-use export control regime, providing more clarity whilst reducing the regulatory burdens in implementing export control requirements by EU exporters. Overall, the proposal sought to balance the objectives of the EU WMD Strategy in the framework of international non-proliferation commitments with promoting competitiveness of EU industry and 'creating the EU of high technology jobs'. ${ }^{47}$ The major proposed items that exceed the technical revision of the Regulation were: the adoption of the 'comitology' procedure for the amendment of annexes; the replacement of authorization requirement for Annex $\mathrm{V}$ items with a pre-notification procedure; the introduction of appropriate civil and criminal penalties to be applied by the Member States for violation of the Regulation's provisions; the legal security for the export of dual use items, particularly with respect to third-country legislations; and the introduction of a negotiation mechanism with third-countries concerning such issues as re-export requirements. ${ }^{48}$ Even though the mentioned comitology procedure would have resulted in an accelerated process of updating lists of controlled items in conformity with the export control regimes, the proposed provision was blocked by the Council and did not find its way in the recast. ${ }^{49}$

\subsection{Key provisions in Regulation 428/2009}

The recast Regulation 428/2009 entered into force in August 2009 and reinforced the Community General Export Authorization (CGEA) for non-EU transfers of certain items, listed in Annex II. ${ }^{50}$ Article 9(2) and Annex III provide that for all other exports that are subject to an authorization requirement, exporting companies shall obtain a license, which is meant to prevent them from cherry-picking and exporting from a Member State with less stringent requirements. ${ }^{51}$ There are four types of licenses under the EU export control regime.

1) The CGEA allows the export of certain dual-use items to certain destinations under certain conditions. There are currently six CGEAs:

a) exports to Australia, Canada, Japan, New Zealand, Norway, Switzerland, Liechtenstein and the U.S.;

b) exports of some types of dual-use items to identified destinations;

c) exports after repair or replacement;

45 Micara (2012) 584-585.

46 Proposal for a Council Regulation setting up a Community regime for the control of exports of dual-use items and technology, $\operatorname{COM(2006)} 829$ final, Brussels, 18.12.2006.

47 Communication from the Commission on the Review of the EC Regime of Controls of Exports of Dual-Use Items and Technology, Brussels, 18.12.2006, COM(2006) 828 final.

$48 \operatorname{COM}(2006) 828$ final 8.

49 Micara (2012) 588.

50 Regulation 428/2009, Article 9.

51 Fiott (2013) 16. 
d) temporary exports for exhibition or fair;

e) telecommunications;

f) Chemicals. ${ }^{52}$

2) National General Export Authorizations (NGEA) should be issued by Member States to exporters established or resident in the authorizing state if they do not overlap with items listed in part 2 of Annex II, and/or meet the requirements set out in the Regulation and national legislation. ${ }^{53}$ Currently, NGEAs are applied in France, Germany, Greece, Italy, Sweden, the Netherlands and the UK. ${ }^{54}$ The Commission shall be notified of any NGEA issued or modified by a Member State.

3) Global Export Authorizations cover several items in several countries of destination or several end-users.

4) Individual licenses are granted by national authorities to an exporter to cover exports of one or more dual-use items to one end-user in a non-EU country. All four types of licenses are granted or denied by the Member State authorities, whereas it is required to notify the Commission of export license refusals. ${ }^{55}$

Furthermore, Article 4, in conjunction with Article 8 of the recast Regulation introduces a 'gulation introduces aticle 8 of the recast Rhorities, whereas it is required to notify the Commission of export license refusals.nd-user in a non-EU country. All four types of licenses in pan particular, Article 4(1) states that an authorization for unlisted items may be required if the exporter has information that the items may be intended for the production and development of chemical, biological or nuclear weapons, other nuclear explosive devices or missiles capable of delivering such weapons. Also, authorization should be required if unlisted items are meant to be transferred to a country subject to an arms embargo. And when the exporter has information that the items are intended for is required to noti

At present, the EU regime of export control of dual-use items consists of Regulation (EC) No. 428/2009 and the Council Joint Action 2000/401/CFSR ${ }^{56}$. EU export controls is claimed to be he Council Joint Action 2000/401/CFSRed to notify the Commission ${ }^{57}$ The Regulation is binding and directly applicable in the Member States, whereas the Joint Action is an intergovernmental cooperation instrument, adopted under the TEU provisions, and which has to be transposed into the Member States' national legislations. ${ }^{58}$ The Regulation has been subsequently substantially amended by Council Regulation (EC) No. 1232/2011, and items listed in Annex I of the Regulation were amended by Council Regulation (EC) No. 388/2012 after the review of the control lists of the Wassenaar Arrangement, the Australia Group, the Missile Technology Control Regime and the Nuclear Suppliers Group during 2009-2010.

52 European Commission Factsheet on The EU Dual Use Export Control Regime, 07/02/2014. Available at $<\mathrm{http} / / /$ ec.europa.eu/trade/import-and-export-rules/export-from-eu/dual-use-controls/> accessed 13 December 2015.

${ }^{53}$ Article 9 (4).

54 Commission factsheet, UNSC Resolution 687 (1991).

55 Fiott (2013) 16.

56 Council Joint Action of 22 June 2000 concerning the control of technical assistance related to certain military end-uses, 2000/401/CFSP, L 159/216.

57 Chapman (2013).

58 Michel (2014). 


\section{CONCLUDING REMARKS}

Article 25 of Regulation 428/2009 states that every three years the European Commission shall review its implementation and present a report to the European Parliament and the Council identifying possible areas of reform. In 2011 the Commission launched a public consultation with the stakeholders concerning the functioning of the current EU export control regime of dual-use items. ${ }^{59}$ Once again, it was stressed that the biggest challenge for the EU is to reconcile the foreign and security objectives with the economic and security objectives. Within the current export controls framework, multiple challenges have been identified by the Member States and other interested parties during the course of public consultation, which command the dynamic enhancement of the export controls regime in the changing world. The challenges include the growing importance of emerging economies, the emergence of new and advanced technologies and the evolution of security risks and threats (terrorism and acquisition by State and non-state actors of WMD). ${ }^{60}$ The consultations and the changes to control lists in the export controls regimes over the course of 2011 and 2013 led the Commission to submit in October 2014 a Proposal to amend Annex I of Regulation 428/2000. ${ }^{61}$

The historic formation of the European export controls regime has experienced a significant shift of competences from the Member States to the Commission. However, the need remains to strike a balance between the Commission'e Commis and the Member States' competences. In view of the EU enlargements and the clear discrepancies in economic and technological development between the older Members and the more recently acceded Members, a more integrated and overarching export controls mechanism is mandatory. Particularly, the Council suggests in the conclusions of the Review of the export control system that adequate information-sharing and transparency among the Member States and a closer cooperation with the private sector is required. This could potentially include the 'E-licensing system' for simplifying administrative procedures and data exchange, as well as a possible introduction of European General Export Authorizations (EGEAs) for facilitating low-risk trade among European companies. In accordance with current discussion, authors of this paper believe providing proper response to existing challenges for EU export control regime consist answers to current questions on its performance in areas of human security, technical advancements, intangible means of technology transfer, and unclear legal terminology existing in the text of regulation. For this purpose further cooperation with partner countries and establishing a continuous dialogue with trading partners, the movement towards global governance model; the reduction of practical divergences amongst EU member states; the definition of more efficient investigative measures for in transit and transshipment controls, the removal of problems on the way for enforcement of controls, and improving collaboration with exporters should be considered in further revision of existing regulation or introduction of new European Export Control Regime on dual-use items.

${ }^{59} \operatorname{COM}(2011) 393$ final.

${ }^{60}$ Commission Staff Working Document, Strategic export controls: ensuring security and competitiveness in a changing world. A report on the public consultation launched under the Green Paper COM(2011) 393, SWD(2013) 7 final, Brussels, 17.1.2013.

${ }^{61}$ Commission Delegated Regulation amending Council Regulation (EC) No 428/2009 setting up a Community regime for the control of exports, transfer, brokering and transit of dual use items, C(2014) 7567 final, Brussels, 22.10.2014. 


\section{LITERATURE}

Anthony, I., Grip, L., 'Strengthening the European Union's Future Approach to WMD nonproliferation' (2013) 37 SIPRI Policy Paper 37.

August, R., Mayer, D., Bixby, M., International Business Law (6th edn, Pearson Education Limited 2013).

Chapman, B., Export Controls: A Contemporary History (University Press of America 2013).

Craig, P., Búrca, G., EU Law: Text, Cases and Materials (5th edn, Oxford University Press 2011)

Fiott, D., Prizeman, K., 'The Arms Trade Treaty and the Control of Dual-Use Goods and Technologies' (2013) 1 IES Working Paper.

Gregory, J. E., 'Controlling the Transfer of Military Significant Technology: COCOM After Toshiba' (1987) 4 Fordham International Law Journal 863-882.

Leslie, B. J., 'Dual Use Goods and the European Community: Problems and Prospects in Eliminating Internal Border Controls on Sensitive Products' (1994) 1 Boston College International and Comparative Law Review 193-211.

Micara, A. G., 'Current Features of the European union regime for Export Control of Dual-Use Goods' (2012) 4 Journal of Common Market Studies 578-593.

Michel, Q., The European Union Dual-Use Items Control Regime, Comment of the Legislation article-by-article, ESU Non-Proliferation, January 2014.

Suzuki, K. , 'Between Trade and Security: EU's Export Control Regime and Its Global Role' (2007) Paper for EUSA Tenth Biennial International Conference, May 17-May 19, 2007, Montreal, Canada, available at < http://aei.pitt.edu/8044/1/suzuki-k-04f.pdf $>$ accessed 13 December 2015.

Wasserstein, R. L., Lazar, N. A., 'The ASA's Statement on P-Values: Context, Process, and Purpose' (2016) 2 The American Statistician 129-133.

Wetter, A., Enforcing European Union Law on Exports of Dual-use Goods. SIPRI Research Report No. 24 (Oxford University Press 2009). 